\title{
Annual Assembly at Rothamsted Experimental Station.
}

'THE annual assembly of subscribers to tho Rothamsted Experimental Station took place on June 18, when demonstrations of the field experiments and of the work going on in the various laboratories were given. As the timo available for the inspection of the fields was short, only a limited number of the trials were inspected; these included the classical experiments on the Park Grass begun in 1856, and the one on the famous Broadbalk wheat field started in 1843 . Tho first was designed to show the effect of different fertiliser treatments on the yicld and character of the herbage, and to-day it forms a very striking illustration of the way in which the farmer can affect the nature of his pasture by varying the plant nutrients supplied. The second experiment was originally intended to show the effect of nitrogen, potash, and phosphorus on the growth of the wheat plant; the action of these throo substances is now well known, but the experiment is still yielding valuable information : for example, a few years ago a study of the yields from the various plots, with the weather records, enabled the statistical department of the station to deduce valuable correlations between rainfall at different seasons of the year and the yield. More recently, by studying the average yield of the plots, the physies department has been led to the study of certain soil charactoristics.

The average yield of the plot receiving a full annual dressing of artificial manure has been very close to that of the plot receiving farmyard manure; but the economic value of the two crops has not been equal, since the dunged plot has yielded relatively more in unfavourable seasons, when prices were higher. It is a matter of great importance to discover why the yields on the dunged plot have been less at the mercy of the vagaries of our climate. The increased microbiological activity induced by the addition of organic matter is undoubtedly the primary reason, and it influences the yield partly by the production of solublo chemical nutrients and partly through the formation of humus, which gives a more open structure to the soil and, incidentally, gives it the black colour characteristic of a 'rich' soil. 'The problem of ascertaining just how the presence of humic mat.ter affects yields is bound up with the wider question of how the nature of the soil and the cultivation treatment it receives influences the growth of the crop and its response to manuring. Work, therefore, on the stability of soil crumbs formed in the field under different systems of cultivation, and by sheep treading, is being followed up in the laboratory, where an attempt is being made to discover the nature of the forces which bind soil particles together. The prosecution of this inquiry has involved excursions into pure science, particularly colloid physics and physical chemistry.

These problems are part of the general one of land utilisation. In many soil surveys only qualitative tests have been applied, owing to the large amount of time and money needed in using the existing laboratory methods. Several new ways of determining the physical properties of a soil have been worked out at Rothamsted. These are quantitative and, at the same time, very rapid. In their development the needs of those responsible for irrigation projects in salty areas have been particularly kept in view.

In addition, however, to the old classical experiments, more modern ones, designed to meet the needs of modern agricultural conditions, have been devised. As an example, the six-course rotation in Long Hoos field and the forage crop in Little Hoos may be cited.

The main object of the six-course rotation is to obtain data by means of which the influence of climatic conditions in different seasons on the response of crop yield to artificial fertilisers may be studied. The rotation is : barley, clover, hay, wheat, potatoes, a forage mixture (rye, beans, and vetches) and sugar beet, and each crop is grown every year. Sulphate of ammonia, superphosphate, and muriate of potash are used, and there is a range of five intensities of manuring for each fertiliser.

The nature of the problems to be investigated in these experiments necessitates continuance over a long period of years, but the immediate results will bo of interest. A feature of the experiment is that the number of years required for a cycle of crops differs from the number required for a cycle of manurial treatments, so that the defect from which older rotation experiments suffered, that the same crop constantly recurred with the same manurial treatment on the same plot throughout the period of experiment, is avoided. It is thus possible to eliminate the effects of pormanent differences in fertility between the plots.

The large experiment of 144 plots, arranged as a Latin square, in Little Hoos field, is designed to investigate the effect of different fertilisers on the yield and chemical composition of forage crops, consisting of mixtures of cereals and legumes. The manuring of such crops presents difficultios which are not encountered when a single crop is grown, since the ability of one constituent to compete with the others in the mixture may be altered by manuring, and the composition and nutritive value of the produce so changed. The main problem is to discover by what system of treatment with artificial fertilisers the yield of protein per acre may be increased. Four different mixtures are used, consisting of : winter oats, vetches, beans ; wheat, vetches, beans; winter oats, peas, beans ; and wheat, peas, beans. The twelve fertiliser treatments include sulphate of arnmonia, nitrate of soda, potassium chloride, and superphosphate, separately and in combination.

Chemical investigations are being carried out on these crops, which should yield interesting information. In 1930 ammonium sulphate increased the amount of cereal straw and depressed that of leguminous plants in mixed forage crops to such an oxtent that the large increase in total yield was not accompanied by any increase in the yiold of protein per acre. Calcium cyanamide generally gives similar results to ammonium sulphate, but under less favourable soil conditions it interferes with the normal nitrification process.

In the afternoon the laboratories were inspected. In the bacteriology department, the investigations made on the nitrogen-fixing bacteria forming nodules on lucerne were explained. In the past this work has led to a large increase in the area of ground on which lucerne can be grown, and special rttention is being paid to the reaction of the organism to the host-plant. This is usually one of mutual benefit; the plant supplying the bacteria with carbohydrates, and receiving in return a supply of nitrogen compounds. If the supply of carbohydrates to the nodule is checked, as by growing the plant in the dark, the bacteria become actively parasitic and destroy the cells of the host.

The entry of tho bacteria into the root is in some way assisted by root secretions of the host-plant, although the manner in which these act is still uncertain.

In the chemistry department, the barley crop is studied in great detail, because its value varies more strikingly than that of any other farm crop with the

No. 3217 , VoL. 127] 
conditions of growth. The amounts of the principal nitrogenous constituents are closely related to the nitrogen contents for a given variety of barley, irrespective of the soil, season, and manuring. Further, many of the properties recognised as important in brewing may be deduced from simple analyses on the original barley, and it should therefore soon become possible to place the valuation of barleys on a more rigid and objective basis. In the course of the work, a successful laboratory technique for small-scale brewings has been developed.

Interesting exhibits were shown by the department of mycology, illustrating racial differentiation and behaviour in fungal species, 'immune' potato varieties infected with wart disease, and the rolation of fungal and host nutrition to potato diseases. There were also demonstrations of the structure and life-history of Bacterium malvacearum and cotton-plants growing in chambers under controlled environmental conditions. In the Empire Marketing Board virus glass-houses, plants were exhibited showing different types of virus diseases; and the physiological, cytological, and entomological aspects of virus research were shown.

In the entomology department, the exhibits illustrated the means of control of Cecidomycidæ (gall midges) affecting osier willows, clover, wheat, and other plants; and experiments dealing with the chemotrophic responses of these insects and the extent to which they govern the selection of the host-plants. The field trials and laboratory observations designed to determine the amount of natural destruction exercised by parasites upon the frit-fly and other agricultural pests were also demonstrated.

The demonstrations gave the visitors some idea of the scope of the work carried on at Rothamsted, although the time at their disposal precluded an exhaustive tour of the fields and the laboratories.

\section{University and Educational Intelligence.}

Belfast.-The Senate has appointed Dr. T. Thomson Flynn to the chair of zoology from Oct. 1, 1931. Dr. Flynn is at present Ralston professor of biology in the University of Tasmania.

CAMrRIDGE.-The Vice-Chancellor gives notice that the Quick professorship of biology will become vacant on Nov. 1 by the retirement of Dr. Nuttall. A meeting of the electors will be held on July 17. The regulations provide inter alia that it shall be the duty of the Professor to devote himself to the study of the biology of the cell and generally to promote that branch of science by research and by the superintendence of a laboratory and otherwise. Candidates are requested to send in their applications to the Vice-Chancellor on or before July 10 .

The Council of the Senate has put forward recommendations for the three John Humphrey Plummer professorships. The chairs are those of mathematical physics, inorganic chemistry, and colloid science.

In the case of the ehair of mathematical physics, it is recommended that it shall be the duty of the professor to promote the study of theoretical physics in connexion with the Department of Physics and the Faculty of Mathematics, with special responsibilities towards research students in the Department of Physics. At the first election, yreferenco shall be given to candidates whose work is connected with atomic physics. Before each election to the professorship after the first, the (General Board shall consult the Council of the School of the Physical Sciences as to the needs of teaching and research in theoretical physics, particularly in connexion with the Department of Physies, and, if the lBoard think fit, it shall be speci- fied in the notice to candidates that preference will be given to those whose work is connected with some particular branch or branches of theoretical physics.

Mr. W. H. Mills, Jesus College, has been elected reader in stereo-chemistry.

GLASGOW.-The honorary degree of LL.D. was conferred on Sir F. G. Hopkins, president of the Royal Society, and on Prof. C. U. Ariëns Kappers, professor at the Central Institute for Brain Research, Amsterdam, at the graduation ceremony held on June 17. At the same graduation, the degree of D.Sc. was conferred on Dr. G. W. Tyrrell for a thesis entitlod "The Geology of Arran".

Lonnon.-Prof. W. W. Jameson, professor of public health in the London School of Hygiene and Tropical Medicine, has been appointed dean of the School, in succession to tho late director, Sir Andrew Balfour.

The following appointments to University Chairs have been made by the Senate: Philosophy (King's College), Dr. H. F. Hallett, since 1919 lecturer in philosophy in the University of Leeds; Medical Industrial Psychology (London School of Hygiene and Tropical Medicine), Dr. Millais Culpin.

The title of Reader has been conferred upon $\mathrm{Mr}$. Sydney Barrát, physical chemistry, University College ; Dr. L. F. Bates, physics, University College ; and Dr. E. A. Spaul, zoology, Birkbeck College.

University postgraduate travelling studentships of the value of $£ 275$ for one year have been awarded to John Stuart Anderson and Eric Gwynne Jones. $\mathrm{Mr}$. Anderson proposes to continue research in the chemistry of the metal carbonyl compounds and rolated substances at Heidelberg. Mr. Jones proposes to carry on spectroscopic research at the astrophysical observatory at Potsdam.

OxFord.-Applications are invited from members of Magdalen College for the Edward Chapman research prize value $£ 20$, for a published piece of original research in physics or chemistry, including the sciences of astronomy, meteorology, mineralogy and geology, zoology and botany, treated from the morphological, palæontological, physiological, or pathological point of view. Further particulars are obtainable from Prof. H. L. Bowman, Magdalen College. Competing essays must bo roceived by, at latest, Oct. 10.

The Foreign Work Committee of Leplay House announces that during the coming August vacation there will be a visit to Poland, including a fortnight in the Carpathians and a few days in Poznan, Cracow, and Warsaw, for historical, geographical, and sociological studies. The studies will be under the direction of Mr. R. E. Dickenson. A meeting will also be held in the Cantal, with Rocamadour and Le Lioran as the centres, under the direction of Mr. D. L. Linton. A students' camp will be held in Yugoslavia. Full particulars may be obtained from Miss Margaret Tatton, Leplay House, 65 Belgrave Road, Westminster, S.W.1.

TrE tenth Unity History School will be hold this year in Stockholm, under the direction of Mr. F. S. Marvin. The general subject will be "The World at Peace: A Survey of Post-War Developments". Both Fnglish and Swedish lecturers will be taking part, among them being Prof. Herbert Dingle, of the Imperial College of Science, who will trace recent progress in the physical sciences; Mr. Hartley Withers, who will deal with financial and economic problems; Mr. Unden, rector of Uppsala and exMinister of Foreign Affairs, on international law; and Archbishop Söderblom, to whom the Nobel

No. 3217 , VoL. 127] 